\title{
PEMBANGUNAN MANUSIA KABUPATEN KEPULAUAN ANAMBAS
}

\section{HUMAN DEVELOPMENT ANAMBAS ISLAND REGIONAL}

\author{
Imam Radianto Anwar Setia Putra \\ Badan Penelitian dan Pengembangan (BPP) Kementrian Dalam Negeri \\ Jl. Kramat Raya No. 132 - Senen, Jakarta \\ No. Telp./Faks : +62 213140454 ; Hp. +62813 61959598 \\ e-mail: imamradianto@gmail.com \\ Dikirim:10 Maret 2015 Direvisi: 10 April 2015 Disetujui: 20 Mei 2015
}

\begin{abstract}
Abstrak
Studi ini bertujuan menjelaskan pembangunan manusia yang dilihat dari capaian nilai indeks pembangunan manusia (IPM) Kabupaten Kepulauan Anambas. Sejak awal pembentukannya selalu menempati posisi rengking akhir IPM tingkat Provinsi Kepulauan Riau. Studi ini menggunakan pendekatan kualitatif dengan data yang didapat melalui wawancara dan focus group discussion. Prioritas program/kegiatan pembangunan manusia dengan menyasar capaian target IPM ditingkat nasional memerlukan singkronisasi dan partisipasi dari seluruh pemangku kepetingan pada perencanaan pembanguanan daerah.
\end{abstract}

Kata kunci: Indek Pembangunan Manusia (IPM), perencanaan daerah, pemangku kepentingan

\begin{abstract}
This study aims to explain human development as seen from the achievements of the human development index (HDI) Anambas Island region. Since the beginning of its formation always end position rengking HDI level Riau Islands Province. This study used a qualitative approach to the data obtained through interviews and focus group discussion. Priority programs/activities targeting the achievement of human development with HDI targets at the national level requires synchronization, and the participation of all stakeholders in the planning area for Development.
\end{abstract}

Keywords: Human Development Indeks (HDI), Urban planning, stakeholders.

\section{PENDAHULUAN}

Manusia menjadi modal dan sasaran utama dalam pembangunan suatu bangsa. Bangsa yang memiliki manusia yang berkualitas baik dapat mendukung dan menjadikan bangsa tersebut menjadi bangsa yang maju. Menurut Todaro (2001), sumber daya manusia dari suatu bangsa merupakan faktor paling menentukan karakter dan kecepatan pembangunan sosial dan ekonomi dari bangsa yang bersangkutan. Sangat penting menjelaskan capaian Indeks Pembangunan Manusia (IPM) Kabupaten Kepuluaan Anambas sehingga menggambarkan pembangunan manusia dan selanjutnya perlu diambil langkah-langkah pendukung dalam program dan kegiatan pemerintah daerah dalam meningkatkan capaian nilainya.

Pentingnya pengukuran Indeks Pembangunan Manusia (IPM) untuk menjaga dan menjadi alat kontorol dalam mendukung peningkatan pembangunan manusia suatu bangsa, negara, dan daerah yang menekankan penigkatan taraf hidup dan kesejahteraann masyarakat dari ketiga indikator. Paradigma IPM memiliki fokus utama dalam pengembangan alternatif ditujukan untuk pengembangan manusia, kemakmuran, keadilan, dan keberlanjutan (UNDP, 2011). Kabupaten Kepuluaan Anambas yang pada tahun 2013 menempati posisi paling akhir diantara seluruh Kabupaten/Kota untuk nilai capaian IPM di Provinsi Kepuluan Riau. Nilai capaian IPM menjadi hal yang paling penting dalam melihat pembangunan mausia yang terjadi khususnya pada Kabupaten Kepuluaan Anambas nilai capaian pada tahun 2013 mencapai nilai sangat 69,50 merupakan data BPS, 2013.

Manusia yang dijadikan sasaran pembangunan suatu bangsa merupakan pilihan utama dalam meningkatkan taraf hidup dan kesejahteraan. Lyncolyn Arsad (2004) menerangkan bahwa pembangunan menepatkan masyarakat sebagai titik pusat dari segenap gerak pembangunan sekaligus sebagai modal dasar keuatan faktor dominan dan sasaran utama pembangunan. Otonomi daerah pada saat ini, memberikan kewenangan yang luas, nyata dan bertanggung jawab kepada Daerah untuk menyelenggarakan pemerintahan dan pembangunan di Daerah. Untuk mendukung pelaksanaan Otonomi Daerah tersebut, kepada Pemerintah Daerah diberikan kewenangan untuk mendayagunakan segala potensi yang dimiliki daerah, seperti sumber daya manusia. Untuk memenuhi tuntutan dalam upaya meningkatkan taraf hidup dan kesejahteraan, peran pemerintah daerah sangat penting dalam menyusun perencanaan dan pengelolaan program/kegiatan demi mendukung capaian maksimal IPM di Kabupaten Kepulauan Anambas yang perlu ditingkatkan lagi. 
IPM Kabupaten Kep. Anambas pada tahun 2011 mencapai angka 68,23 dengan penilaian pembangunan manusia menengah tinggi. Pada tahun 2011 juga Angka Harapan Hidup (AHH) sebesar 67,53 artinya manusia yang lahir pada tahun 2011 memiliki usia 67,53 tahun dimana AHH menjadi indikator dari aspek kesehatan. Selanjutnya angka melek huruf (AMF) mencapai angka 91,87 bersama angka rata-rata lama sekolah (ARLS) 6,38 pada tahun 2011 yang merupakan bagian dari indeks pendidikan, dan angka konsumsi ril per Kapita pada tahun 2011 mencapai 629,07 yang merupakan indeks daya beli (IDB) yang berasal dari aspek pendapatan. Informasi dari data tersebut menggambarkan IPM Kabupaten Kep. Anambas dengan nilai capaian yang rendah di wilayah Provinsi Kep. Riau menjadi view dalam melihat pembangunan manusia.

Melalui ukuran indeks pembangunan manusia ini, masyarakat dapat memonitor perkembangan dan pemerintah dapat dimintai pertanggungjawabanya (Wirokartono, 2009). Dengan demikian pemerintah daerah perlu merencanakan dan menyiapkan aksi dalam mendorong tercapaian nilai yang ditetapkan tersebut. tantangan dalam perencanaan dengan masih rendahnya capaian IPM Kabupaten Kap. Anambas tidak terlalu berlebihan kiranya dilakukan usaha untuk mendongkrak angka IPM tersebut menjadi angka yang lebih baik lagi dalam analisis ini. Perencanaan program/kegiatan dan skenario dalam keterpaduan pelaksanaannya menjadi upaya dalam peningkatan pencapaian nilai IPM menjadi perhatian. Selain nilai capaian yang didapat pada saat ini, usaha yang dapat ditempuh baik dalam perencanaan dan pelaksanaan kegiatan menjadi agenda kebijakan yang merupakan titik masuk bagi pemerintah Pemerintah Kabupaten Kep. Anambas guna meningkatkan nilai capaian IPM.

IPM merupakan penilaian terhadap pembangunan manusia menurut pengertiannya dalam Human Development Report 2013 "Human Development Index (HDI): A composite index measuring average achievement in three basic dimensions of human development-a long and healthy life, knowledge and a decent standard of living.”. pengertian ini menjelaskan Indeks Pembangunan manusia menjadi alat ukur melihat pembangunan manusia melalui tiga dimensi dasarnya dari indeks tersebut. Pembangunan manusia disatu daerah dihitung dengan menggunakan Indeks Pembangaunan Manusia merupakan indeks komposit yang mengukur pembangunan manusia di suatu negara/daerah, UNDP (1990) pembangunan manusia merupakan model pembangunan yang ditujukan.

IPM merupakan suatu indeks komposit yang mencakup tiga bidang pembangunan manusia yang dianggap sangat mendasar yaitu umur harapan hidup, pengetahuan, dan standar hidup layak. (BPS,2010). Indeks Pembangunan Manusia dibangun dengan 3 (tiga) apek utama, antara lain: 1) Kesehatan; 2) Pendidikan; 3) Pendapatan. angka Harapan Hidup
(AHH) menjadi indikator dari aspek kesehatan, angka melek huruf (AMF) bersama angka rata-rata lama sekolah (ARLS) menjadi indeks pendidikan, dan yang terkahir angka konsumsi ril per Kapita menajadi indeks daya beli (IDB) yang berasal dari aspek pendapatan. UNDP menetapkan yang dasar indeks pembangunan manusia antaralain: usia hidup (longevity) diukur dari angka harapan hidup waktu lahir, pengetahuan (knwoledge) dan standar layak hidup (decent living).

Penjelasan pada Tabel 1, IPM dibagi kedalam 4 kategori antara lain: diantaranya nilai IPM yang masuk kedalam IPM kategosi rendah yaitu dengan nilai IPM 50 kebawah, kategori ke dua yaitu kategori menengah rendah IPM dengan nilai 50 sampai dengan 66, kategori menengah tinggi yaitu IPM dengan nilai 66 sampai dengan 80 dan kategori tinggi dengan nilai IPM 80. Keempat katogori pada tinggkatan IPM tersebut memberikan pemaknaan

Tabel 1. Nilai dan Status Pembangunan Manusia

\begin{tabular}{cc}
\hline Nilai & $\begin{array}{c}\text { Stasus Pemembangunan } \\
\text { Manusia }\end{array}$ \\
\hline$\leq 50$ & Rendah \\
\hline $\begin{array}{c}50 \leq \text { IPM }< \\
66\end{array}$ & Menegah Rendah \\
\hline $66 \leq$ IPM $<$ \\
80
\end{tabular}

terhadap pembangunan manusia suatu bangsa/daerah. Pada pencapaiannya nilai IPM memiliki rentang nilai yang menjadi dasar untuk menetapkan penilaian pembangunan manusia, tadi ketiga indeks yang membangun nilai capaian nilai IPM tersebut setiap indikator memiliki penilaian yang maksimum yang harus dicapai.

Melihat angka serta nilai capaian dari indeks pembangunan manusia, tentunya pemerintah menyusun strategi dalam perencanaan yang mengarahkan pada program/kegiatan yang akan dilakaukan untuk mentukan pembangunan manusia. PP 8/2008 tentang tahapan, tata cara penyusunan juga menekankan peningkatan Indeks pembanguanan manusia dalam perencanaan pembangunan daerah. Sejalan dengan itu, Pembangunan manusia merupakan perwujudan tujuan jangka panjang dari suatu masyarakat dan meletakkan pembangunan di sekeliling manusia, bukan manusia di sekeliling pembangunan (Yunita, 2012 dalam Dewi S dan Ketut Sutrisna, 2014). Peningkatan kualitas manusia sebagai sasaran dalam pembangnunan jangka panjang perlu direncanakan dengan baik sehingga capaian yang menjadi sasaran dapat diwujudkan 
dalam pembangunan daerah. Pembangunan mutu modal manusia yang diwakili oleh Indeks Pembangunan Manusia dengan ketiga komponennya meliputi indeks kesehatan, indeks pendidikan dan indeks daya beli masyarakat haruslah benar-benar menjadi perhatian Pemerintah. (Dewi S dan Ketut Sutrisna, 2014). Pemerintah dalam melakukan perencanaan dan pembangunan harus memperhatikan capaian ketiga Indeks tersebut sehingga dari tiap capaian nilai indeks menggambarkan kemajuan pembangunan.

\section{Tabel 2. Capaian Nilai Maksimum Dan Minimum IPM}

\begin{tabular}{|c|c|c|c|}
\hline $\begin{array}{l}\text { Komponen } \\
\text { IPM } \\
\text { Angka } \\
\text { Harapan } \\
\text { Hidup } \\
\text { (AHH) }\end{array}$ & $\begin{array}{c}\text { Nilai } \\
\text { Maksimum } \\
85\end{array}$ & $\begin{array}{c}\text { Nilai } \\
\text { Minimum } \\
25\end{array}$ & $\begin{array}{l}\text { Keterangan } \\
\text { Standar } \\
\text { UNDP }\end{array}$ \\
\hline $\begin{array}{l}\text { Angka } \\
\text { melek } \\
\text { huruf } \\
(\mathrm{AMH})\end{array}$ & 100 & 0 & $\begin{array}{l}\text { Standar } \\
\text { UNDP }\end{array}$ \\
\hline $\begin{array}{l}\text { Rata-rata } \\
\text { lama } \\
\text { sekolah } \\
\text { (MYS) }\end{array}$ & 15 & 0 & $\begin{array}{l}\text { UNDP } \\
\text { Menggunak } \\
\text { an combined } \\
\text { gross } \\
\text { enroiment }\end{array}$ \\
\hline $\begin{array}{l}\text { Daya Beli } \\
(\mathrm{DBM})\end{array}$ & 732.720*) & $\begin{array}{l}300.000 \\
\ldots \ldots . \\
(1990) \\
360.000 \\
\ldots \ldots . \\
(1996) \\
* *)\end{array}$ & $\begin{array}{l}\text { UNDP } \\
\text { Menggunak } \\
\text { an PDB rill } \\
\text { per kapita } \\
\text { yang telah } \\
\text { disusun }\end{array}$ \\
\hline
\end{tabular}

\section{METODE}

Studi ini, menggunakan pendekatan kualitatif dengan didukung metode deskriptif yang menggambarakan penyelenggaraan pembangunan manusia dengan merujuk pada capaian setiap indeks pembangunan manusia yang ada dan melihat berbagai upaya yang dilakukan oleh pemerintah daerah dengan mengana;isis strategi dalam program/kegiatan guna mendukung peningkatan IPM. Data yang dikumpulan, merupakan data primer yang didapat dari hasil diskusi kelompok terfokus dan data sekunder yang didapat dari dokumendokumen penyelenggaraan pemerintah.

Kabupaten Kepulan Anambas merupakan daerah otonomi yang baru terbentuk pada pada tanggal 21 Juli 2008 dengan Undang-undang nomor 33 tahun 2008 tentang pembentukan Kabupaten
Kepulauan Anambas. Saat ini masih berusia 5 (lima) tahun. Daerah otonom yang masih relatif muda masih pada tahap mempersiapkan pondasi awal untuk mendukung penyelenggaraan pemerintah. pada periode awal ini menjadikan tantangan bagi seluruh penangku kepentingan penyelenggaran pemerintahan Kabupaten Kepulauan Anambas untuk saling bergoyong royong menyiapkan segala infrastruktur fisik dan fisik untuk memenuhi kesejahteraan masyarakat.

Melihat posisi dan letak wilayah kabupaten Kepulauan Anambas yang terletak di daerah terluar indonesia dan berbatasan laut dengan beberapa negara tetangga indonesia seperti Malaysia, Singapura, Thailand, Vietnam, menjadikan garda terdepa dalam mendukung teritorial wilayah keamanan Negara Kesatuan Republik Indonesia. Selain itu, daerah otonom ini masuk kedalam alur laut kepulauan Indonesia II (ALKI II) yang merupakam jalur pedagangan laut yang ada di indonesia yang menjadikan daerah ini terletakpada wilayah strategis.

Kabupaten Kepulauan Anambas terdiri atas 7 (tujuh) kecamatan berciri kepulauan yang mencakup 238 buah pulau dan memiliki wilayah seluas $46.664,14 \mathrm{Km}^{2}$ atau $2,47 \%$ dari luas Indonesia (1.890.754 $\left.\mathrm{Km}^{2}\right)$. Luas wilayah didominasi oleh wilayah laut (maritime), yakni mencapai 46.033,81 $\mathrm{Km}^{2}$ (98,73\%), sedangkan luas daratan hanya 1,27 $\%$ atau seluas $592,14 \mathrm{Km}^{2}$. Adapun panjang garis pantainya mencapai $1.128,57 \mathrm{Km}^{2}$, termasuk 5 (lima) pulau terluar yang berbatasan langsung dengan negara tetangga (Malaysia dan Vietnam). Dari sejumlah pulau yang ada, hanya 26 pulau berpenghuni, sedangkan 212 pulau belum berpenghuni (termasuk kelima pulau terluar). Dukungan sumber daya dan potensi wilayah yang banyak dimiliki menjadi modal dasar dalam pembangunan manusia kabupaten kepulaan anambas. Sudah beroprasinya 5 (lima) ladang minyak lepas pantai dan juga merupakan perlintasan kabel serat optik bawah laut dan penyupai gas bagi singapuara menjadi sangat cukup berarti bagi pembangunan manusia di kabupaten anambas.

Merupakan wilayah kepulauan dibutuhkan sarana prasarana transportasi dan pola pengembangan wilayah dengan berbagai macam pendekatan yang disesuaikan dengan karateristik wilayah kepulauaanya yang menjadi faktor utama dalam pembangunan. Pembangunan manusia di kabupaten kepulauan anambas juga tidak lupa menitik beratkan kepada pendukungan terhadap sektor pengelolaan kelautan yang merupakan potensi yang cukup besar menjadi modal. Dengan terbukanya akses tersebut masyarakat akan mudah mendapatkan segala sesuatu dalam memenuhi kebutuhan hidup. Dengan mudahnya mencari dan mengakses kebutuhan hidup tersebut masyarakat akan memanfaatkan kondisi tersebut untuk mencari 
nilai manfaat untuk dapat meningkatkan kualitas kehidupannya.

Terkait dengan pembangunan manusia, selain infrastruktur yang dibangun juga pembangunan manusia menyentuh kualitas masyarakat di Anambas. Tingkat pendidikan yang ditempuh dan dukungan sarana prasarana pendidikan yang tersedia menjadi faktor utama dalam peningkatan mutu dan taraf hidup masyarakat. Penilaian IPM merupakan cerminan penilaian pembangunan manusia yang dapat mengukur pembangunan manusia dari penilaian fisik dan non fisik indikator yang dapat dilihat dalam penilaian tercermin dari angka harapan hidup, yang mengukur julaitas fisik dan yang mengukur kualitas non fisik (intelektualitas) melalui lamanya rata-rata masyarakat bersekolah dan angka melek huruf; juga mempertimbangkan kemampuan ekonomi masyarakat di wilayah itu; tercermin dari nilai daya beli masyarakat. Jadi indikator IPM lebih komprehensif. IPM muncul dalam untuk menjawab tantangan dalam meninlai pembangunan daerah yang hanya terbatas pada pendapatan perkapita (Sjafrizal, 2009) sedangkan pembangunnan daerah tidak hanya
Melihat reduksi shortfall (r) merupakan pengukuran tingkat kemajuan terhadap kinerja pembangunan manusia yang dilakukan oleh pemerintah daerah dengan melihat berbagai angka dari pencapaian program/kegiatan yang diimplementasikan dalam suatu periode tertentu, yang dinotasikan kedalam rumus reduksi shortfall per tahun (annual reduction shortfall). Kabupaten kepulaun Anambas yang mencapai 2,87 merupakan angka pencapain tertinggi untuk Provinsi Kepuluan Riau, juga jika dibandingkan dengna nilai pencapaian provinsi yang mencapai 2,83 juga memiliki kecepatan pencapaian “Cepat” memiliki kemampuan yang besar dalam memenuhi tuntutan nilai IPM.

IPM Kabupaten Kepulauan Anambas pada tahun 2011 nilai capaian yang diraih sebesar 69,50 yang berada pada posisi menengah atas. Posisi ini sudah cukup baik rasanya, tapi jika melihat capaian yang didapat oleh pemerintah daerah lainnya pada provinsi Kepulauan Riau, dirasa masih sangat belum memuaskan karena berada posisi paling akhir diantara Kabupaten/kota. Target RPJMD untuk capaian indeks tersebut menjadi sasaran untuk

Tabel 3. Perkembangan IPM dan Laju Pertumbuhan Rata-rata IPM

Kabupaten/Kota di Provinsi Kepulauan Riau, Tahun 2008-2011

\begin{tabular}{|c|c|c|c|c|c|c|c|}
\hline \multirow[t]{2}{*}{ No } & \multirow[t]{2}{*}{ Kabupaten/ Kota } & \multicolumn{4}{|l|}{ IPM } & \multirow{2}{*}{$\begin{array}{l}\text { Rata-rata Laju } \\
\text { Pertumbuhan } \\
\end{array}$} & \multirow{2}{*}{$\begin{array}{l}\text { Reduksi } \\
\text { Shortfall }\end{array}$} \\
\hline & & 2008 & 2009 & 2010 & 2011 & & \\
\hline$(1)$ & $(2)$ & (3) & (4) & (5) & (6) & (7) & $(8)$ \\
\hline 1 & Karimun & 72,8 & 73,15 & 73,64 & 73,99 & 0,54 & 1,33 \\
\hline 2 & Bintan & 73,34 & 73,66 & 74,44 & 75,17 & 0,83 & 2,84 \\
\hline 3 & Natuna & 69,81 & 70,11 & 70,56 & 71,26 & 0,69 & 2,38 \\
\hline 4 & Lingga & 70,74 & 71,05 & 71,35 & 71,68 & 0,44 & 1,14 \\
\hline 5 & Kep Anambas & 67,44 & 67,94 & 68,6 & 69,5 & 1,01 & 2,87 \\
\hline 6 & Batam & 77,28 & 77,51 & 77,8 & 78,03 & 0,32 & 1,07 \\
\hline 7 & Tanjung Pinang & 73,92 & 74,31 & 74,59 & 75,25 & 0,60 & 2,57 \\
\hline 8 & Kepulauan Riau & 74,18 & 74,54 & 75,07 & 75,78 & 0,71 & 2,83 \\
\hline
\end{tabular}

Sumber: IPM Kabupaten Kepulauan Anambas, 2011

mencakup aspek ekonomi, tetapi juga aspek sosial seperti pendidikan dan drajad kesehatan.

\section{HASIL DAN PEMBAHASAN}

\section{Indeks Pembangunan Manusia Dalam Kebijakan Pembangunan Daerah}

Indeks Pembangunan Manusia (IPM) tahun 2011 Kabupaten Kepulauan Anambas tidak bergerak signifikan, berada pada posisi 7 dari 7 Kabupaten/Kota yang ada diwilayah Provinsi kepulauan Riau. Pada pembangunan manusia di Kabupaten Kepulauan Anambas berdasarkan ratarata laju pertumbuhan IPM selama 4 (empat) tahun terakhir mencapai 1,01. Kerja Pemerintah Daerah sudah nampak secara statistik. Kabupaten Kepulauan Anambas menempati posisi pertama untuk rata-rata laju pertumbuhan dibandingkan keenam daerah lainya yang pertumbuhanya hanya dibawah angka 1 (satu) terlihat dari angka reduksi Shortfall (r). menilai dan mengarahkan berbagai bentuk strategi, program/kegiatan pembangunan daerah sehingga dapat meningkatkan nilai capaian indeks tersebut. Nilai indeks yang ditetapkan dalam dokumen RPJMD merupakan bentuk keyakinan dan kepercaan diri dari pemerintah daerah untuk menetapkan lebih baik lagi nilai capai indeks tersebut. Pemerintah daerah harus dapat secara-benar memperhatikan kemampuan serta kebutuhan yang menjadi dasar dari masyarakat. Hal tersebut dapat dilihat pada Tabel 3.

Capaian saat ini menjadi suatu tantangan yang dihadapi dalam perencanaan pembangunan daerah nilai capain IPM tahun 2011 dengan capaian IPM dalam RPJMD 2010-2015 menjadikan cerminan bagi penetapan kebijakan berupa pemilihan dan penentuan berbagai program/kegiatan yang tepat dalam menyasar outcome dari setiap target capaian yang menjadi pengerak nilai IPM. Target capaian dalam RPJMD merupakan sasaran yang harus dipenuhi melalui berbagai program/kegiatan yang dilakukan oleh pemeritah daerah untuk sesegera 
mungkin meningkatakan nilai capaian dimaksud. Terkait capaian IPM 2011 dan Target IPM dalam RPJMD dapat dijelaskandalam Tabel 4. kembali oleh bagian perencanaan baik yang ada di tingkat SKPD ataupun pada Bappeda. Sehingga memiliki daya ungkit dalam pencapaian target dan

Tabel 4. Nilai Capaian IPM 2011 dan Target IPM dalam RPJMD

\begin{tabular}{ccccc}
\hline Indeks & $\mathbf{2 0 1 1}$ & Target RPJMD & $\mathbf{2 0 1 5 - 2 0 1 1}$ & $\begin{array}{c}\text { Pertumbuhan } \\
\text { per tahun }\end{array}$ \\
\hline AHH & 67,53 & 68,27 & 0,74 & 0,185 \\
AMH & 91,87 & 92,04 & 0,17 & 0,0425 \\
ALS & 6,38 & 11,88 & 5,5 & 1,375 \\
DBM & 629,07 & - & - & - \\
\hline
\end{tabular}

Sumber: RPJMD 2010-2015 dan IPM Kab Kepulauan Anambas, data dioleh, 2013

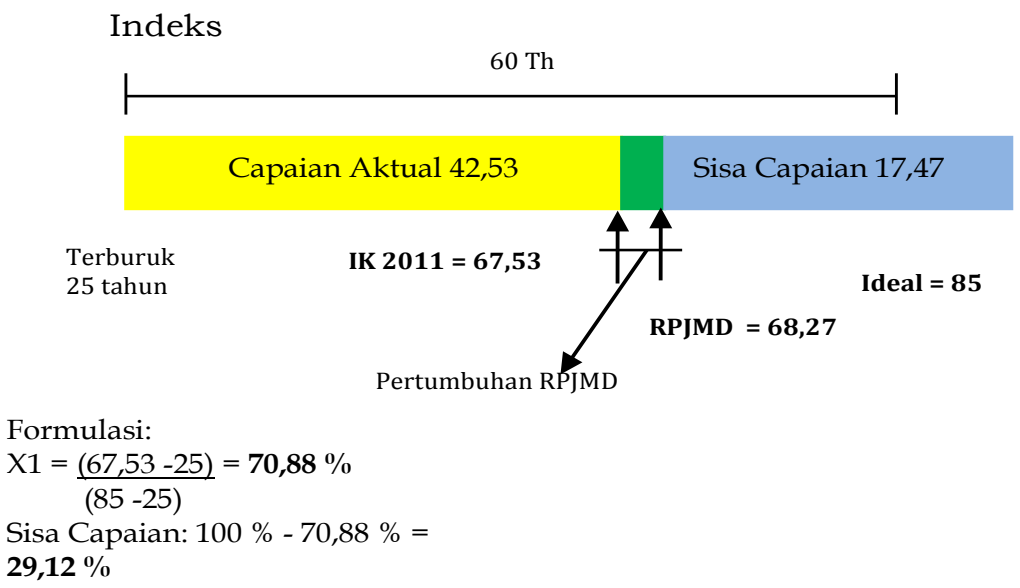

Gambar 1. Capaian dan Sasaran Angka Harapan Hidup

\section{Indeks Kesehatan}

Pada Gambar 1, angka harapan hidup pada tahun 2011 mencapai 67,53 tahun, artinya manusia yang lahir pada tahun 2011 diharapkan usianya dapat mencapai 67,53 tahun, sedangkan untuk target RPJMD sendiri hanya mencapai 68,27 tahun, yang memiliki arti masyarakat Kabupaten Kepulauan Anambas yang lahir pada tahun 2015 diharapkan dapat mencapai usia 68,27 tahun. Target IPM angka harapan hidup maksimal masyarakat di suatu wilayah mencapai 85 tahun, ada jarak pencapai target angka harapan hidup dari target RPJMD kepada nilai maksimum sebanyak 16,73 tahun.

Melihat data dari pergerakan nilai pencapaian dari tahun 2011 kepada target RPJMD tiap tahunnya hanya bergerak 0,185 begitu lambat capai yang menjadi sasaran yang ditetapkan. Lambatnya pergerakan tersebut perlu dipacu oleh pemerintah daerah sehingga memiliki tingakat kewajaran dalam target pencapaiannya. Berbagai cara dan strategi dalam mewujudkan pelaksanaan visi dan misi melalui strategi yang digunakan dalam setiap prgoram dan kegiatan yang ada pada setiap urusan pemerintah daerah khususnya pada bidang kesehatan perlu mendapatkan perhatian dan dihitung ulang nilai capai.

Untuk dapat mengejar dan meningkatkan nilai capaain IPM khususnya indeks pendidikan dari daerah lain dalam Provinsi Kepulauan Riau, perlu dilakukan revisi pada perencanaan dengan memperhatikan beberapa aspek yang menjadi dukungan pelaksanaan pencapaian nilai capai IPM meningat kemampuan sumberdaya yang tersedia serta meningkatkan partisipasi masyarakat kedalam program dan kegiatan untuk meningkatkan nilai capain angka harapan hidup tersebut. Partisipasi masyarakat, tidak bisa dipisahakan dalam miningkatkan kesadaran dari setiap individu masyarakat untuk berprilaku dihidup sehat dilingkungannya dengan demikian antara perencanaan dan keterlibatan masyarakat yang tinggi dapat saling mendukung untuk sesegera mungkin pencapaian nilai tersebut.

\section{Indeks Pendidikan}

Selain angka harapan hidup yang menjadi target dalam perencanaan daerah dalam peningkatan menusia di kabupaten Kepuluan Anambas juga melihat nilai capaian IPM, indeks rata-rata lama sekolah yang merupakan salah satu indeks pendidikan yang diukur. Dalam RPJMD indeks 
pendidikan tersebut mencapai 5,5 tahun pada tahun 2015 dimana angka rata-rata lama sekolah pada tahun 2011 6,38 tahun. Tahun 2015 menjadi 11, 8 tahun artinya waktu pendidikan yang ditempuh oleh masyarakat Kabupaten Kepulauan Anambas pada tahun 2015 menembus tamat Sekolah Menegah Atas (SMA). Penjelasan tersebut dapat dilihat pada Gambar 2. ditetapakan pencapaian indeks pendidikan menitik beratkan pada pengadaan infrastruktur serta konektivitas wilayah yang menjadi kunci untuk dapat memenuhinya sehingga target tersebut dapat terlampaui di periodesasi awal terbentuknya kabupaten Kepuluan Anambas. Metode belajarmengajar yang bersinergi dengan ketersediaan infrastruktur wilayah menjadi perpaduan yang tepat

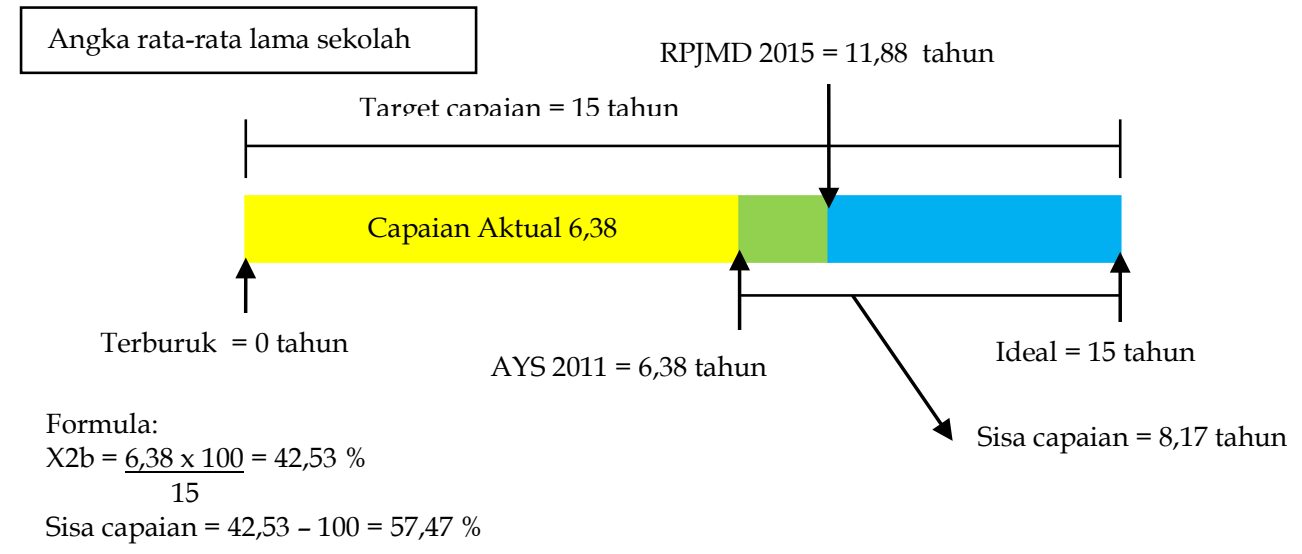

\section{Gambar 2. Angka Rata-Rata Lama Sekolah}

Tantangan yang dihadapi saat ini besarnya masyarakat yang belum banyak mengenal baca dan tulis dan terdapat pada jejang usia 40-lansia juga tantangan lainnya dari kelompok usia tersebut mendapatkan hambatan dalam diri setiap masingmasing idnividu untuk dapat mau ikut dalam proses belajar, dengan demikian diperlu strategi yang dapat mendorong minat keikut- sertaan dalam proses belajar khusus yang sudah menjadi bagian strategi dari pemerintah.

Topografis wilayah juga merupakan salah satu tantangan tersendiri dimana masyarakat tersebar di berbagai pulau-pulau yang ada sehingga untuk menamatkan pada jenjang pendidikan yang lebih tinggi infrastruktur pendidikan tersebut terletak dibeberapa pulau tertentu, ini menjadi pemicu bagi pemerintah daerah untuk menentukan langkah dan strategi dalam peningkatan indeks pendidikan. Melihat perencanaan yang dilakukan oleh pemerintah daerah dari program/kegiatan yang untuk dapat segera merealisasikan angka capain tersebut.

Penetapan dalam perencanaan daerah, angak rata-rata lama sekolah pada tahun akhir RPJMD di tahun 2015 ditetapakan mencapai 11,88 tahun artinya daya ungkit melalui berbagai kebijakan yang dilakukan oleh pemerintah daerah rata-rata waktu pendidikan yang ditempauh oleh masyarakat di Kabupaten Kepuluaan Anambas mencapai pada lulusan sekolam menengah atas, melihat pergerakannya di tahun 2011 angkat capain tesebut mencapai 6,38 tahun yang artinya rata-rata masyarakat baru menamatkan jenjang pendidikan sekolah dasar. Pergerakan nilai capaian angka ratarata lama sekolah dalam rencana pembangunan daerah selama 5 (lima) tahun 5,5 tahun. Pergerakan ini memang membutuhkan jaminan agar telaksanan dengan baik dari seluruh pihak, baik pemerintah, masyarakat, dan para pelaku dunia pendidikan di Kabupaten Kepuluaan Anambas. 
Jika dilihat semangat dalam RPJMD target yang ditetapkan pada tahun 2015 mencapai 11,88 tahun yang artinya masyarakat Kabupaten Kepulauan Anambas mampu menamatkan pendidikan 11 tahun 8 bulan yaitu pada posisi tamat Sekolah Menengah Atas atau setingkatnya (SMA/MA/SMK) target pertumbuhan pencapaian dari tahun 2011 kepada tahun berakhirnya RPJMD di tahun 2015 mencapai
Pertumbuhan pada angka rata-rata lama sekolah merupakan angka petumbuhan yang paling tinggi diantara angka pertumbuhan untuk indeks lainya pembangun IPM Kabupaten Kepulauan Anambas. Menunjang pencapaian angka rata-rata lama sekolah tersebut pemerintah daerah hingga saat ini sudah menyediakan berbagai infrastruktur pendidikan, baik berbentuk fisik bangunan dan

Tabel 5. Persentase Jumlah Masyarakat yang Menamatkan Pendidikan Diatas Usia 15 tahun

\begin{tabular}{lcccc}
\hline No & Pendidikan yg Ditamatkan & Laki-Laki & Perempuan & Total \\
\hline 1 & Tidak/belum pernah bersekolah & 8,14 & 10,98 & 9,67 \\
2 & Tidak/belum tamat SD & 26,09 & 26,05 & 26,07 \\
3 & SD/MI & 30,98 & 30,58 & 30,79 \\
4 & SMP/MTs & 11,25 & 13,17 & 12,19 \\
5 & SMA/MA/SMK & 17,05 & 12,56 & 14,84 \\
6 & Akademi/Universitas & 6,22 & 6,65 & 6,43 \\
\hline & Total & 100 & 100 & 100 \\
\hline
\end{tabular}

Sumber: IPM Kabupaten Kep. Anambas

angka 5,5 tahun yang rata-rata pertumbuhan nilai capaian rata-rata lama sekolah pertahunnya dari tahun 2011 sampai dengan 2015 mencapai 1,37 tahun.

Setelah menelusuri angka rata-rata lama sekolah dilanjutankan pada Angka Melek huruf yang merupakan bagian dari Indeks pendidikan, target pencapaian pergerakan angka melek huruf ini menjadi pemicu untuk meningkatkan nilai indkes pendidikan dengan memperhatikan Kemampuan baca dan menulis dari seluruh masyarakat. Capaian angka melek huruf yang ditetapkan dalam rencana pembangunan daerah di tahun 2011 sampai 2015 hanya bergerak pada 0,0425 pertahunnya atau pergerakan selama 2011 hingga tuntasnya pelaksanaan RPJMD pada tahun 2015 hanya berkisar 0,17. Pergerakan yang sangat lambat tersebut dan keinginan untuk meningkatkan posisi IPM pada tingkat regional memerlukan perhatihan khusus dalam perencanaan dan mengawal pelaksanaanya. tenaga pendidiknya. Jumlah tenaga pendidik dan strategi penyelenggaraan pendidikan dirasakan menjadi faktor yang paling mendukung untuk peningkatan nilai capaian rata-rata lama sekolah.

Pada Gambar 3, Capaian angka melek huruf tahun 2011 di Kabupaten Kepulauan Anambas mencapai angka 91,87 \% yang juga sekaligus merupakan capaian aktual yang artinya 91,87 \% dari jumlah masyarakat di Kabupaten Kepulauan Anambas sudah mampu baca dan tulis diatas usia masyarakat 10 tahun. Kebijakan yang diambil dalam meningkatkan laju pertumbuhan angka melek huruf meningkatkan minat baca-tulis melalui kegiatan yang langsung mengikut sertakan masyarakat di dalamnya. Pembukaan ruang baca bagi masyarakat dengan tema-tema buku disesuaikan dengan latar belakang pekerjaan menjadi salah satu strategi, yang dihadapi saat ini adalah minimnya minat baca pada usial putus sekolah dan kelompok masyarakat yang lanjut usia

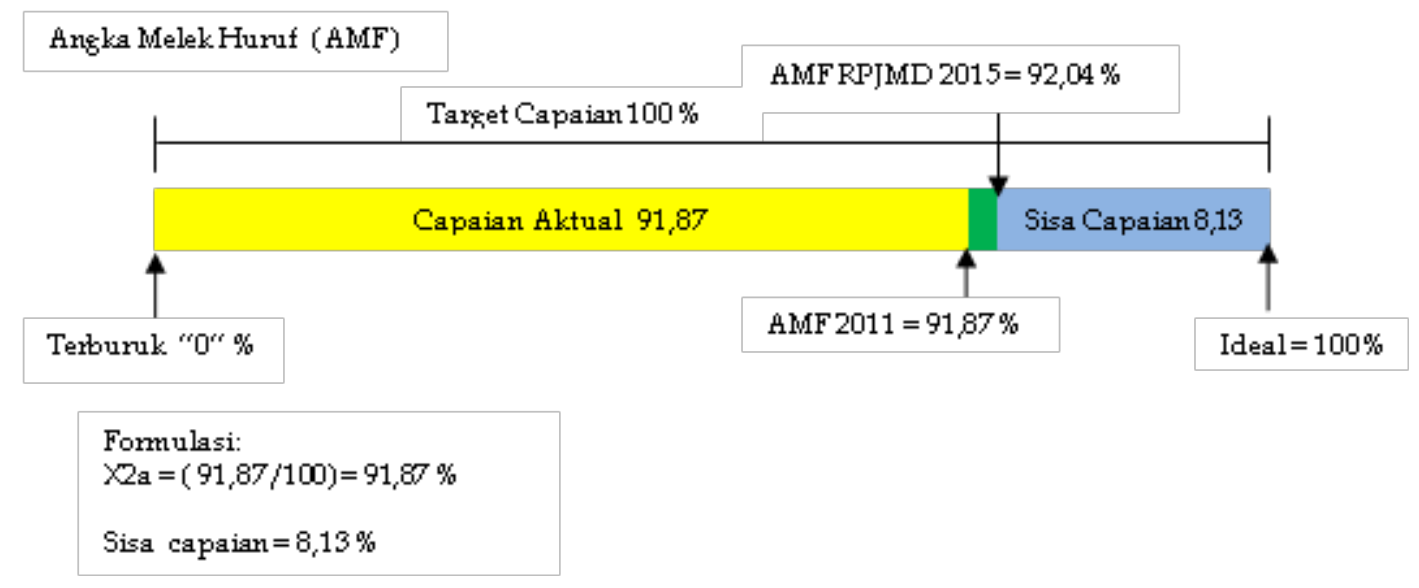

Gambar. 3. Capaian dan Sasaran Angka Melek Huruf 
Memperhatikan sisa capai angka melek huruf hanya mencapai 8,13 yang menjadi tugas pemerintah daerah untuk menuntaskan masyarakat agar dapat baca dan menulis, untuk mendeteksi pada tingkatan usia mana yang memiliki kemampuan baca dan tulis rendah disajikan pada Tabel 6. dan diatas 50 tahun yang memiliki tingkat pendidikan masih rendah menjadi sasaran utama pemerintah daerah dalam mempersiapkan program/kegiatan yang tepat.

Tabel 6. Persentase Masyarakat Melek Huruf Usia 10 Tahun Keatas

\begin{tabular}{lcccc}
\hline No & $\begin{array}{c}\text { Kelompok } \\
\text { Umur (th) }\end{array}$ & $\begin{array}{c}\text { Laki-laki } \\
(\mathbf{\%})\end{array}$ & $\begin{array}{c}\text { Perempuan } \\
(\mathbf{\% )}\end{array}$ & $\begin{array}{c}\text { Laki-laki + } \\
\text { Perempuan (\%) }\end{array}$ \\
\hline$(1)$ & $(2)$ & $(3)$ & $(4)$ & $(5)$ \\
\hline 1 & $10-14$ & 97,92 & 97,58 & 97,75 \\
2 & $15-19$ & 98,30 & 98,98 & 98,54 \\
3 & $20-24$ & 96,39 & 96,99 & 96,65 \\
4 & $25-34$ & 95,81 & 94,90 & 95,36 \\
5 & $35-49$ & 94,06 & 85,99 & 90,44 \\
6 & $50+$ & 84,83 & 76,52 & 80,60 \\
7 & $10+$ & 93,73 & 91,07 & 92,43 \\
\hline
\end{tabular}

Sumber: IPM Kabupaten Kepulauan Anambas, 2012

Kelompok umur 50 keatas merupakan kelompok umur yang memiliki capaian nilai paling rendah dalam angka melek huruf, yaitu mencapai angka 80,60 \%. Konsentrasi pemerintah daerah pada masyarakat usia 50 keatas menjadi perlu ditingkatkan setidaknya berbagai alternatif pelaksanaan pendidikan melalui kejar paket menjadi salah satu upaya yang dapat diterapkan dalam mendorong untuk meningkatkan angka capaian melek huruf. Sasaran dalam peningkatan angka melek huruf yang paling banyak pada usia 50 tahun keatas dan juga kelompok masyarakat usia 35-49 tahun untuk itu, memperhatikan kondisi geografis wilayah kepulauan yang masyarakatnya tersebar di berbagai pulau yang ada. Menjadi salah satu bentuk pelaksanaan kegiatan belajar mengajar yaitu, metode dan pola pengajaran yang diberikan juga menjadi perhatian SKPD terkait dalam proses belajarmengajar mengingat usia yang menjadi sasaran dalam peningkatan minat para masyarakat tersebut. Pendekatan pendidikan untuk usia diatas 34 tahun

\section{Indeks Daya Beli}

Sedangkan untuk indeks daya beli masyarakat dalam RPJMD belum diterjemahkan berapa target pencapaianya sedangkan capaian pada tahun 2011 indeks daya beli ini sudah mencapai sebesar 629.070 yang artinya rata-rata pendapatan perkapita masyarakat pada tahun 2011 mencapai angka 629.070 sedangkan nilai maksimum untuk pencapaian angka daya beli masyarakat ini mencapai 732,720 yang merupakan perkiraan maksimum dalam Perencanaan Jangka Panjang (PJP) II 2018. Terdapat nilai selisih dari capaian indeks daya beli masyarakat pada tahun 2011 dengan nilai maksimun yang ditetapkan, sehingga hasil yang didapat harus segera dipenuhi agar mencapai posisi 103,650. Uraian tersebut dapat dilihat pada Gambar 4.

Pengalian pendapatan asli daerah untuk mendorog pendapatan daerah regional bruto dalam meningkatkan daya beli masyarakat menjadi sasaran bagi pelaksanaan kebijkan ekonomi daerah. penguatan sendi-sendi ekonomi pada tingkat

Target capaian 432.720

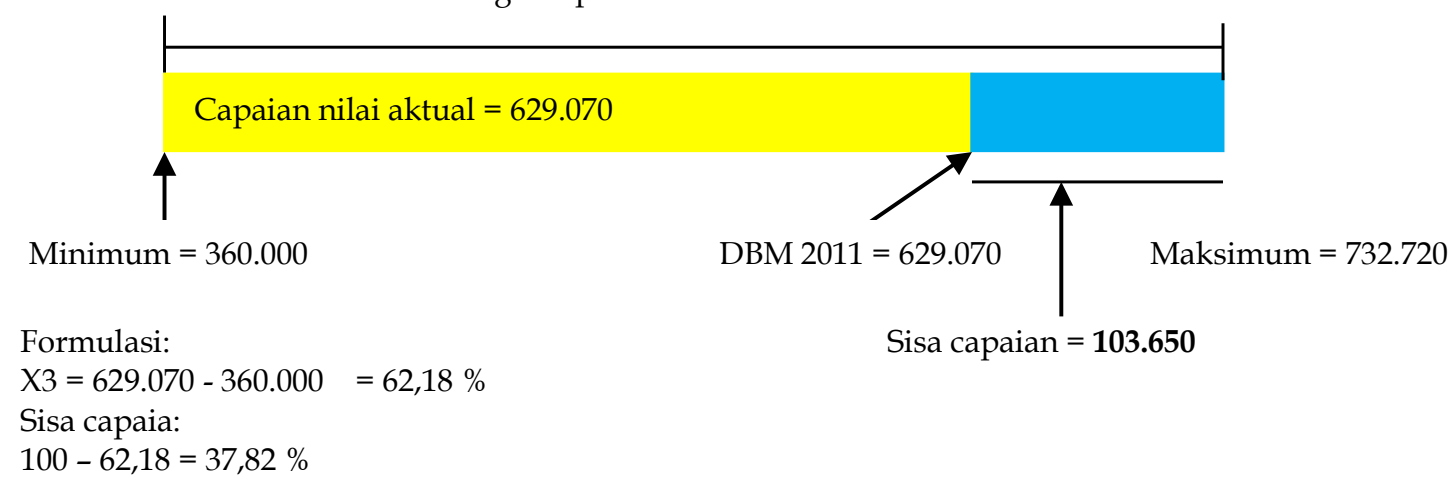

Gambar 4. Indeks Daya Beli Mayarakat 
masyarakat ditataran bawah dengan menyiapkan dan membangun fasilitas produksi barang dan permodalan menjadi penekanan yang tidak kalah pentingnya kebijkan yang pro maysarakat sehingga masyarakat mampu mengembangakan kemampuan berusaha. Saat ini, lemahnya kemampuan masyarakat untuk membangun suatu usaha, keinginan yang besar sangat dirasakan sayangnya kurangnya fasilitasi dan dukungan permodalan menjadi tantangan bagi pemerintah saat ini.

Selain itu, distribusi pendapatan dimasyarakat masih belum merata terlihat masih besarnya masyarakat yang belum dapat mengelola secara terampil dan terlatih usaha yang dijalankan, konsumsi makanan dimana bahan dasarnya sebagaian besar didatangkan dari luar daerah dan juga Masyarakat juga seringkali membelanjakan uangnya untuk memenuhi kebutuhan hidupnya sehingga perputaran tidak begitu dirasakan. Untuk itu, kiranya perencanaan dengan kebijakan yang tepat terutama dalam menyiapkan berbagai kebutuhan dan memfasilitasi masyarakat dalam membangun usaha sekala menengah dan kecil menjadi salah satu langkah yang dapat dipertimbangankan.

Langkah kedepannya dalam memenuhi capaian IPM, pemerintah daerah perlu menelusuri kembali dan melakukan evaluasi terhadap berbagai program dan kegiatan serta nilai capaian yang telah ditetapkan dalam RPJMD Kabupaten Kepulauan Anambas. Untuk itu integrasi berbagai program yang dibuat serta yang direncanakan menjadi hal yang sangat penting dalam mendukung dan memadu serasikan semuanya sehingga pencapaian nilai IPM yang diharapkan dapat terwujud.

\section{Strategi Peningkatan Indeks Kesehatan}

Angka capaian indeks kesehatan sebesar 67,53 tahun pada tahun 2011 tersebut menjadi tantangan tersendiri bagi pemerintah Kabupaten Kepulauan Anambas untuk mendekatkan ke angka maksimal yang sudah ditetapkan. Tantangan saat ini dan kedepannya dimulai dari ketersediaan infrastruktur fisik kesehatan tersebut yang merupakan sebuah wujud komitmen nyata dari pemerintah daerah sendiri dalam memberikan pelayanan yang lebih baik dan lebih dekat dengan masyarakat dengan harapan masyarakat akan menjadi sehat dan mendorong peningkatan capaian nilai Indeks Kesehatan di Kabupaten Kepulauan Anambas. Promosi kesehatan menjadi tindakan kuratif dalam pencengahan dan penyehatan lingkungan masyarakat

Promosi kesehatan ini merupakan salah satu pendekatan dalam meningkatkan partisipasi masyarakat untuk menjaga lingkungan dan setiap masing-masing individu untuk menciptakan lingkungan yang sehat. Kebijakan promosi kesehatan menjadi salah satu alternatif yang dapat dimanafaatkan saat ini oleh pemerintah dalam mengupayakan peningkatan indeks kesehatan Menurut Green (dalam, Notoatmodjo, 2005), promosi kesehatan adalah segala bentuk kombinasi pendidikan kesehatan dan intervensi yang terkait dengan ekonomi, politik, dan organisasi, yang dirancang untuk memudahkan perilaku dan lingkungan yang kondusif bagi kesehatan. Dirasakan sangat minim dari beberapa hasil diskusi promosi kesehatan yang dilakukan oleh pemerintahan daerah, saat ini pemenuhan sarana-prasarana fisik dan SDM memang jadi kebijakan dalam mendorong dan meningkatkan indeks kesehatan sayangnya promosi kesehatanya sangat minim dilakukan sehingga berdampak pada indeks kesehatan. Kegiatan ini juga diharapkan adanya partisipasi masyarakat untuk turut serta dalam mendukung dan menjaga kesehatan setiap masing-masing individu masyarakat sehingga dari partisipasi masyarakat tersebut dapat mendorong terciptanya dukungan dalam meningkatkan nilai capaian Indeks Kesehatan.

Selain itu, ketersediaan jumlah tenaga kesehatan dan juga menjamin kompetensi seluruh tenaga kesehatan menjadi hal yang baik guna mendukung terciptanya pelayanan kesehatan kepada masyarakat yang nantinya diharapkan dapat meningkatkan Indeks Kesehatan. Jumlah tenaga kesehatan yang saat ini ada perlu ditambahkan sehingga terjamin dan menjaga kualitas pelayanan kepada masyarakat, tambahan tenaga kesehatan ini juga melihat kebutuhan dari wilayah Kabupaten Kepulauan Anambas yang merupakan terdiri dari pulau-pulau yang dipisahkan laut disekelilingnya. Selain itu untuk menjaga kualitas pelayanan disetiap unit kesehatan baik di Rumah Sakit maupun di Puskesmas perlu dilakukan uji kompetensi untuk tenaga kesehatan dengan mengikutsertakan dalam pelatihan atau Diklat tambahan yang terkait dengan penanganan kesehatan dan penyakit masyarakat.

Pelaksana tenis seperti dibutuhkan perawatan yang tepat dalam lama penanganan pasien atau masyarakat yang sakit, ketersediaan obat-obatan yang tepat dan jenis obat-obatan paten yang dapat dengan segera menyembuhkan penyakit yang diderita oleh pasien atau masyarakat. Obat-obatan paten tersebut kiranya sangat dibutuhkan oleh masyarakat dengan menyesuaikan kebutuhan dari jenis penyakit yang sudah diidentifikasi selama ini. selain itu untuk menjaga kualitas kesehatan dan menekan angka lama sakit masyarakat, dibutuhkan tindakan kuratif dalam mempromosikan perilaku hidup sehat kepada masyarakat untuk pencegahan berbagai macam jenis penyakit yang banyak diderita oleh masyarakatTidak hanya pada penanganan pengobatan masyarakat saja tetapi dalam menjaga dan meningkatkan kesehatan masyarakat dibutuhkan juga berbagai tindakan pencegahan atau tindakan kuratif untuk mencegah masyarakat terjangkit penyakit. 
Usaha yang dilakukan pemerintah dalam meningkatkan Indeks Kesehatan melalui beberapa program dan kegiatan turut menjadi perhatian dalam perencanaan pemerintah daerah Kabupaten Kepulauan Anambas. Dukungan terhadap balita dan ibu melahirkan juga menjadi penekanan pada Indeks Kesehatan ini dan juga banyak upaya pemerintah yang sudah dilakukan untuk mendorong pelaksanaan kegiatan kesehatan dengan sasaran balita dan tingkat persalinan ibu. Penting juga dalam menjaga kesehatan ibu, anak dan lansia dalam menjaga kesehatan dan menghidari terjangkitnya suatu penyakit dalam menjaga perilaku hidup sehat dan meningkatkan Indeks Kesehatan.

Intensitas penyelenggaraan pos pelayanan terpadu atau yang lebih dikenal POSYANDU menjadi kebutuhan bagi masyarakat Kabupaten Kepulauan Anambas. Posyandu ini menjadi salah satu upaya tindakan kuratif bagi masyarakat untuk menjaga kesehatan ibu, balita dan lansia dengan menyelenggarakan berbagai promosi kesehatan yang terkait dengan menjaga kesehatan dan pelaksanaan imunisasi bagi balita atau pun lansia untuk menjaga kualitas hidup dan taraf hidup khususnya pada bidang kesehatan.

Penting menjaga mutu dan kualitas penyelenggaraan kesehatan dalam upaya meningkatkan capaian Indeks Kesehatan. Dukungan sarana prasarana kesehatan juga SDM yang berkualitas dan jaminan terhadap kompetensi yang melekat pada pekerjaan sebagai tenaga kesehatan serta ditambah dengan peningkatan partisipasi masyarakat. Peram aktif masuyarakat dalam jaga tingkat kesehatan sendiri menjadi bagian yang tidak tepisahlan melalui penciptaan pola hidup sehat dan sosialisasi hal tersebut.

Tantangan terbesar pada daerah kepulauan yaitu aksesabilitas masyarakat yaitu kemudahankemudahan yang didapatkan guna mendapatkan pelayanan kesehatan, upaya pemerintah daerah Kabupaten Kepulauan Anambas sudah cukup nampak dengan menyiapkan puskesmas keliling untuk di daerah, puskesmas laut untuk menjangkau pulau-pulau terpencil di wilayah Kabupaten Kepulauan Anambas. Sarana penunjang dirasa saat ini sudah tersedia dan memadai untuk mendukung pelaksanaan urusan kesehatan perlu upaya dari masyarakta untuk berperan aktif dalam penyelenggaraan kegiatan kesehatan.

\section{Strategi Peningkatan Nilai Capaian Pendidikan}

Pendidikan menjadi salah satu indikator endogen dari IPM, Indeks Pendidikan dibangun dari 2 nilai yang telah ditetapkan yaitu angka melek huruf dan angka rata-rata lama sekolah. Dua nilai ini menentukan nilai capaian Indeks Pendidikan dan juga sebagai penilaian kinerja pemerintah daerah dalam membangun bidang pendidikan. semakin baik tingkat pendidikan dan kemampuan masyarakat dalam menamatkan jejang pendidikan tertingi, mendobrak mutu hidup manusia pada Indeks Pendidikan di Kabupaten Kepulauan Anambas. di bawah ini disajikan ilustrasi pencapaian angka melek huruf yang dijadikan salah satu indeks capaian untuk Indeks Pendidikan.

Rendahnya tingkat pendidikan yang dicapai oleh masyarakat di Kabupaten Kepulauan Anambas membutuhkan stategi penguatan dalam ketersediaan sarana membaca dan kesempatan untuk dapat mempuh pendidikan pada tingak desa sekali pun. Dengan memperhatikan karakteristik wilayah kepulauan, tantangannya disini konektivitas dan aksesabilitas masyarakat terhadap infrastruktur pendidikan yang tersedia dan tersebar di wilayah Kabupaten Kepulauan Anambas serta juga kompetensi pendidikan yang dibutuhkan oleh wilayah kepulauan untuk dapat mendorong pembangunan sesuai dengan potensi dan sumber daya yang dimiliki oleh wilayah ini. jumlah tenaga pendidikan yang masih perlu ditingkatkan serta stetegi pengelolaan pendidikan menjadi hal yang sangat penting guna peningkatan nilai capaian indek pendidikan.

Partisipasi aktif dari pemerintah daerah dalam membuat kebijakan untuk meningkatkan minat baca menjadi sangat penting mulai dari kelompok usia termuda hingga tertua. Perlu adannya kebijakan yang berpola rangsangan bagi masyarakat dan sosialisasi dunia pendidikan hingga kepelosok desa. rangsangan terbebut bisa penyediaan berbagai literatur ataupun referensi di dalam perpustakaan berjalan dan pemberian bimbingan melalui guru-guru sekolah selepas jam pelajaran bagi masyarakat dengan kelompok umur 40 (empatpuluh) keatas. Selain itu optimalisasi perpustakaan keliling dan perlombaan menulis cerita atau artikel dapat dijadikan sebagai bentuk rangksang bagi masyarakat berusia muda.

Pola dan strategi penyelenggaraan pendidikan yang tepat dalam meningkatkan minat para murid untuk dapat menyelesaikan pendidikannya pada jenjang yang lebih tinggi merupakan salah satu bentuk target yang harus disusun perencanaanya oleh pemerintah daerah Kabupaten Kepulauan Anambas. Sehingga penyelenggaraan pendidikan yang murah dan dapat terjangkau oleh masyarakat menjadi rangsangan untuk menamatkan pendidikan pada jenjang setinggi-tingginya untuk dapat mendongkrak Indeks Pendidikan Kabupaten Kepulauan Anambas. Juga diharapkan pemerintah daerah juga merencanakan dan juga membangun infrastruktur fisik pendukung untuk pendidikan nonformal dan informal guna menarik minat masyarakat pada kelompok usia 34 -50 tahun keatas untuk mampu baca tulis.

Selain itu juga, pemberian beasiswa diharapkan dapat menstimulasi masyarakat di daerah untuk mau malanjutkan dan meningkatkan kualitas pendidikan kepada jenjang pendidikan yang lebih tinggi. Pembiayaan pendidikan terkait dengan dukungan terhadap sarana transportasi guna 
mendekatkan akses masyarakat terhadap sarana dan prasarana pendidik juga menjadi perhatian bersama pada jajaran pemerintah daerah, sehingga koordinasi yang dibangu dalam jajaran pemerintah daerah dapat memberikan dampak yang cukup singnifikan dalam peningkatan nilai capaian Indeks Pendidikan.

Tenaga pendidik yang ada saaat ini diharapkan menjaga kompetensi dan profesionalismenya dalam kegiatan belajar. Optimalisasi pelaksanaan tugasnya, pendidikan dan pelatihan serta pemberian motivasi merupakan hal yang tidak boleh ditinggalkan. Pemberian kesempatan mengikuti pelatihan dan promosi karir menjadi salah satu motivasi extrinsik yang kirannya patut diberikan berdasarkan pertasi yang dibuat guna meninkatkan partisipasi pendidikan oleh masyarakat,

Selain itu perekrutan tenaga pendidik yang memang disesuaikan pada kebutuhan pengelolaan sumberdaya dan potensi yang dimiliki oleh daerah itu sendiri. Kompetensi menjadi penting untuk menjaga kualitas tenaga pendidik/ guru, dimana menjaga kualitas pada proses belajar yang dilakukan sehari -hari dan juga dibutuhkan pendidikan tambahan guna peningkatan kemampuan guru dalam menyampaikan ilmu dan pengetahuan kepada peserta didik.

Pendistribusian dan pembagian guru diwilayah Kabupaten Kepulauan Anambas perlu menjadi pemikiran bersama untuk sehingga pemerataan jumlah guru yang menangani murid atau usia sekolah dapat menopang pendidikan dan jumlah kebutuhan tenaga pendidik. Menjadi arah kebijakan untuk pengelolaan tenaga pendidik di Kabupaten Kepulauan Anambas sehingga diharapkan dengan demikian penyebaran guru tersebut dapat memberikan manfaat pada peningkatan kualitas pendidikan yang diterima oleh peserta didik.

Selain tenaga pendidik/guru, ketersediaan infrastruktur fisik pendidikan juga menjadi kebutuhan yang sangat nyata dilapangan jika melihat ketersediaan infrastruktur fisik yang ada diperlukan beberapa penambahan dengan letaknya yang sangat stretegis sehingga bisa dijangkau oleh para peserta didik/murid. Di bawah ini disajikan tabel dalam melihat ketersediaan sekolah di Kabupaten Kepulauan Anambas.

\section{Mendongkrak Daya Beli Masyarakat}

Daya beli masyarakat yang merupakan kemampuan masyarakat dalam kegiatan ekonomi di daerah menjadi ukuran pada IPM. Indeks daya beli masyarakat dibangun dari beberapa indikator ekonomi yang ada pada Kabupaten Kepulauan Anambas. Produk Domestik Bruto (PDRB) menjadi salah satu indikator makro ekonomi yang menjadi salah satu indikator penghitungan indeks daya beli masyarakat. Saat ini capaian angka daya beli masyarakat Kabupaten Kepulauan Anambas pada tahun 2011 mencapai 629.070. Target perencanaan dalam upaya peningkatan indeks daya beli masyarakat adalah angka 103.650 atau 36,82 \% yang harus dicapai sehingga sampai pada angka dan mendekati angka 732.720. Pemerintah daerah harus mencari strategi dan membangun kebijakan yang taktis demi indeks daya beli masyarakat tersebut dapat menyentuh angka maksimalnya.

Untuk itu setiap indikator ekonomi mikro yang membentuk indeks daya beli ini menjadi sasaran untuk ditingkatkan dalam perencanaan pembangunan daerah. Melihat sektor ekonomi mikro pada Kabupaten Kepulauan Anambas yang ditopang dari berbagai sektor pembangunan di daerah yang mengelola potensi dan sumberdaya yang dimiliki oleh daerah. Sektor pertambangan dan penggalian mengalami peningkatan pesat dalam laju pertumbuhan ekonomi mencapai 8,76 Persen (BPS KKA, 2011) dan diikuti oleh sektor perikanan.

Penguatan pada sektor perikanan dan kelautan menjadi suatu hal yang sangat penting, mengingat sumberdaya dan potensi alam terbesar yang dapat dikelola oleh masyarakat secara langsung dan cepat mendatangkan manfaat atau keuntungan yang cukup dapat membuat masyarakat dapat memenuhi kebutuhan hidupnya, sayangnya perikanan dan kelautan setidaknya dijadikan sebuah industri yang bisa mendatangkan manfaat dan multiplayer efek yang dapat meningkatkan gairah masyarakat untuk mengelola potensi dan sumberdaya perikanan lebih efektif dan ekonomis.

Membangun industri perikanan tangkap ataupun perikanan perairan membuka kesempatan kerja bagi masyarakat di daerah dan juga tentunya perlu ditopang dengan Sumber Daya Manusia yang memiliki skill dan pengetahun pada bidang pengelolaan perikanan tersebut yang dapat dihasilkan dari penyelenggaraan pendidikan yang dibangun oleh pemerintah daerah sendiri. Juga tak kalah pentingnya bidang pertambangan dimana Kabupaten Kepulauan Anambas menjadi daerah penghasil minyak dan gas bumi yang saat ini sudah terdapat 5 (lima) perusahaan pengeboran minyak bumi lepas pantai dan juga perusahaan pengeboran gas bumi. Penyelenggaraan pendidikan sangat dibutuhkan untuk mendukung dan meningkatkan Sumber Daya Manusia yang dibutuhkan oleh lapangan kerja yang tersedia. Dengan demikian antara penyelenggaraan pendidikan dengan kebutuhan terhadap lapangan kerja yang ada di Kabupaten Kepulauan Anambas bisa saling terkait dan mendorong pembangunan pendidikan melalui pemenuhan kebutuhan pasar kerja.

Di semua sektor perekonomian pada tahun 2011 hampir semua lapangan usaha mengalami pertumbuhan yang positif dan juga sektor perikanan dengan memiliki wilayah perairan yang cukup luas menunjukan hasil yang signifikan yaitu nilai pertumbuhan mencapai 61,31 \%. Ada 3 sektor pada nilai makro ekonomi yang memiliki pertumbuhan tertinggi, antara lain: konstruksi, pertambangan dan penggalian, perdaganan, restoran dan perhotelan, 
ditambah sektor dalam PDRB yaitu sektor pertanian dan lainnya.

Terdapat 4 sektor besar yang mengisi indikator mikro ekonomi di Kabupaten Kepulauan Anambas. Rangsangan dari pemerintah daerah dengan telah adanya perusahaan daerah yang akan menjadi pemicu pergerakan perekonomian sangat dibutuhkan. Penggalian sektor pariwisata, transportasi, dan industri perkapalan perlu mendapat perhatian yang serius dalam mendorong dan usahausaha pembangunan sektor baru produksi, sehingga dengan terbukanya berbagai sektor baru dalam upaya mendukung dan meningkatan pendapatan masyarakat diharapkan akan meningkatkan dukungan terhadap peningkatan daya beli masyarakat.

Selain itu juga dukungan permodalan yang mendorong usaha-usaha masyarakat menjadi bergerak sehingga membawa perubahan struktur ekonomi di masyarakat. Setidaknya pembangunan lembaga usaha mikro mendorong terciptanya koperasi atau berdirinya kelompok-kelompok usaha baru di masyarakat sehingga dapat mendorong minat masyarakat untuk terjun langsung dalam pelaksanaan kegiatan perekonomian. Dorongan terhadap pemasaran hasil bumi berupa pertanian lokal dapat membuka jalur pemasaran guna membuka dan mengenalkan hasil produksi lokal seperti hasil pertanian dan perikanan yang dikelola oleh masyarkat Kabupaten Kepulauan Anambas.

Penggalian potensi pada sektor minapolitan dan industri pendukungnya diharapkan juga dapat segera terealisasi dalam mendukung dan menunjang perekonomian di Kabupaten Kepulauan Anambas untuk itu perlu ketersediaan tenaga kerja yang memiliki skill dan pengetahuan yang baik dalam mendukung industri tersebut. Penyediaan industri tersebut bisa di dapat dengan pengelolaan bersama antara pemerintah daerah dengan perusahaan daerah yang sudah berdiri. Sinergitas tersebut akan membangun kerangka perekonomi yang baik sekaligus memicu sektor swasta untuk mau turut bergabung dalam perekonomi di daerah.

\section{KESIMPULAN}

1. Penelusuran kembali kebijakan dalam perencanaan pembangunan daerah yang erat kaitannya dengan menekankan pada kegiatan dasar dalam memenuhi setiap indeks pembentuk IPM.

2. Menelusuri secara konferhensif seluruh program dan kegiatan yang dibuat sehingga nantinya akan direncanakan pencapaian indeks yang lebih realisitis dengan dukungan pendanaan yang tersedia.

3. Perencanaan yang matang dalam mendukung pelaksanaan melalui integrasi Program/Kegiatan SKPD Secara Sinergis Dalam Upaya Akselerasi \& Peningkatan IPM
4. Keterpaduan dan sinergitas dalam penyusunan serta penetapan kebijakan dari seluruh SKPD yang nantinya mendukung pencapaian indeks dalam penyusuana perencanaan daerah.

5. Memberikan Penguatan Kelembagaan \& Peningkatan Kapasitas SDM Aparatur dengan memperkuat kelembagaan yang memiliki kompetensi yang baik dalam penyelenggaraan pemerintah daerah sehingga dapat mendukung peningkatan angka perolehan IPM.

\section{Daftar Pustaka}

Arsad, Lincolin, 2004. Ekonomi Pembangunan. Yogyakarta: STIE YKPN.

BPS Kabupaten Kepuluan Anambas, 2012. Indek Pembangunan Manusia Kabupaten Kepuluan Anambas 2011. BPS.

Bappeda Kabupaten Kepuluan Anambas, 2010. Rencana Pembangunan Jangaka Menegah Daerah (RPJMD). Bappeda.

Dewi, N.L Sartika dan Sutrisna, I Ketut, 2014 Jurnal Ekonomi Pembangunan Universitas Udayana vol. 3, No. 3, 106-114.

Notoatmodjo, S. 2005. Promosi Kesehatan \& Ilmu Perilaku. Rineka Cipta, Jakarta.

Sjafrizal. (2009). Teknsk Praktis Penyusunann Rencanan Pembangunan Daerah Baduose Media, Sumatra Barat.

Todaro, Michael. 2001. Pembangunan Ekonomi di Dunia Ketiga. Jakarta: Erlanga United Nations Development Programme (2011), Human Development Report 2011, Sustainability and Equity: A Better Future for All. UNDP: USA.

United Nations Development Programme (2013) Human Development Report 2013 The Rise of the South: Human Progress in a Diverse World. UNDP: USA

Wirokartono, S. Dkk, 2009. Pembangunan Provinsi Gorontalo: Perencanaan Dengan Indeks Pembangunan Manusia. BRIDGE: Jakarta. 